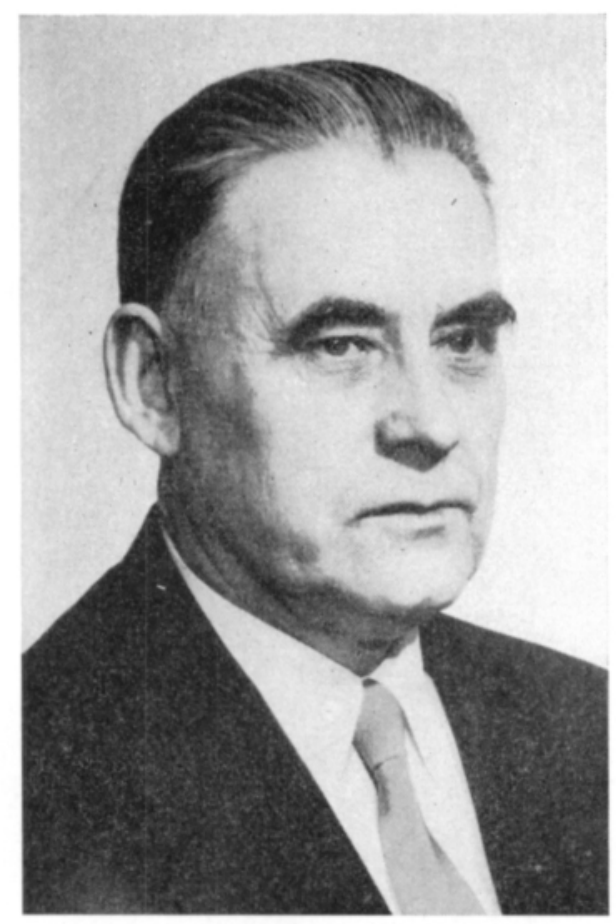

\title{
PAAVO A. VIDING ${ }^{1}$
}

\author{
* 7. 3. $1899-\dagger 19.8 .1965$
}

Elokuun 17. päivänä 1965 siirtyi vuorineuvos, agronomi Paavo A. Viding sen rajan taakse, josta ei ole paluuta. Hän oli karjalainen — syntynyt Jääskessä 7. 3. 1899 - ja hänen työnsä kohdistui aluksi nimenomaan kotimaakunnan hyväksi, mutta laajeni sittemmin käsittämään koko maan, jopa ulottui sen rajojenkin yli. Suoritettuaan agronomitutkinnon 1924 hän työskenteli aluksi Kuopion maanviljelysseurassa, mutta siirtyi pari vuotta myöhemmin Viipurin maanviljelysseuraan maanviljelyskonsulentiksi. On syytä muistaa, että maamme itsenäistymisen johdosta erityisesti rajaseudut ja niiden joukossa Karjalan kannas olivat joutuneet aivan uusiin taloudellisiin oloihin sen johdosta, että kaikki aikaisemmat kauppatiet Neuvostoliittoon päin olivat sulkeutuneet. Karjalaisen väestön oli löydettävä uusia elämän mahdollisuuksia ja siinä suhteessa neuvontaelimillä oli erittäin tärkeä ja velvoittava tehtävä maatalousväestön ohjaamisessa uusille urille. Oli onnellista että maatalouden neuvontaa olivat siellä suorittamassa sellaiset henkilöt, jotka osasivat oikein suhtautua väestöön ja ennen kaikkea antaa heille päteviä ohjeita. Tässä suhteessa agronomi Viding oli mies paikallaan. Hän tunsi olosuhteet ja hän

1 Suomen Maataloustieteellisen seuran kokouksessa 31. 9. 1965 pidetty muistopuhe 
tiesi mihin suuntaan kehitystä oli johdettava. Karjalainen väestö osoittautui jo silloin joustavaksi. Se otti nopeasti neuvosta vaarin ja uutta peltoa raivattiin, uusia viljelyskasveja ryhdyttiin viljelemään ja kotieläinkantaa lisättiin. Esimerkkinä mainittakoon, että vehnämyllyjä syntyi muutamiin pitäjiin jopa useitakin ja Kannaksen kevätvehnän hyvä laatu tuli pian yleisesti tunnetuksi. Tämä nopea ja myönteinen kehitys antoi aiheen siihen, että 1932 Viipurissa pidettiin koko maata käsittävä maatalousnäyttely. Tässä kaikessa kehityksessä oli Paavo Viding johtavana sieluna ja taitavana ohjaajana.

V. 1931 hän siirtyi Maatalousseurojen keskusliiton maanviljelystalouden konsulentiksi, joten hänellä oli koko valtakunta työmaanaan. Mutta pian Karjala veti hänet jälleen puoleensa. V. 1937 perustettiin Antreaan raakasokeritehdas ja se tarvitsi innokkaan ja tarmokkaan johtajan ja sai sellaisen Paavo Vidingistä. Tässä yhteydessä on syytä panna merkille, että 1930-luvulla suoritettiin Karjalassa Hannilan koeasemalla sokerijuurikkaan viljelyskokeita ja selvitettiin sen hoito- ja lannoituskysymyksiä. Näissä kokeissa tuli mm. esille boorilannoituksen välttämättömyys. Karjalainen maanviljelijä perehtyi sangen pian sokerijuurikkaan viljelyyn ja sen erikoisuuksiin ja siellä saatiin hyviä satoja. Sotavuodet keskeyttivät tämän nopeasti kehittyvän uuden viljelyskasvin niinkuin kaiken muunkin viljelemisen.

V. 1940 agronomi Viding siirtyi Maatalousseurojen keskusliiton jälleenrakennusja asutusvaliokunnan puheenjohtajaksi, jossa tehtävässä hänelle avautui erityisen laaja mutta vaikea työ takaisinvallatun alueen jälleenrakentamisessa. Tämä työ, joka ei suinkaan rajoittunut vain Karjalan kannakselle, vaan ulottui myös Laatokan Karjalaan oli voimia ja taitoa kysyvä. Rakennustarvikkeita oli niukasti ja samalla oli myös huolehdittava elintarvikkeiden tuottamisesta, mutta niin jälleenrakentajia kuin heidän johtajiaankin elähdytti halua saada tuhottu Karjala pian entiseen kukoistukseensa. Valitettavaa vain, että nämä takaisin vallatun alueen hyväksi tehdyt parannukset osittain tuhoutuivat sodan myöhemmissä vaiheissa ja alue jouduttiin sittemmin kokonaan luovuttamaan vieraan käsiin.

V. 1946 Viding kutsuttiin Maatalousseurojen keskusliiton toiminnan johtajaksi. Kun hän vuosina 1946-48 oli lisäksi maatalousministerinä, niin hänen kokemuksensa, tietonsa ja taitonsa tulivat erinomaisesti koko valtakunnan jälleenrakentamisessa hyväksikäytetyksi. Karjalainen siirtoväki sai hänestä tuen, jonka puoleen usein jouduttiin kääntymään ja joka suurenmoisella tavalla oli apuna mitä moninaisimmissa vaikeuksissa.

V. 1949 Viding siirtyi SOK:n pääjohtajaksi, mutta hänen välitön kosketuksensa maatalouteen ei siitä suinkaan heikentynyt, vaan päinvastoin hän oli jatkuvasti kiinteässä yhteydessä erilaisten maatalousjärjestöjen kanssa. SOK:n johtajana hänen toimintansa ulottui yli koko valtakunnan ja tässä asemassa hän suoritti erinomaisen päivätyön. Hänen johtajakaudestaan osa sattui vilkkaimpaan jälleenrakennuskauteen ja osa uuteen nopeaan taloudelliseen kehityskauteen, mikä luonnollisesti tuntui erittäin voimakkaasti suuren keskusliikkeen piirissä. On luonnollista, että SOK:n jatkuva kehittäminen oli Vidingin tavoitteena, mutta samalla hän korosti osuustoiminta-aatteen tärkeyttä ja välttämättömyyttä. Tähän niinkuin kaikkeen toimintaansa hän oli painanut vakavan, isänmaallisen leiman. 
En tässä käy selostamaan niitä monia muita tehtäviä, joita Viding oli päätyönsä ohella saanut suoritettavakseen ja jotka kaikki hän tunnollisesti vei päätökseen. Meidän on täällä Maataloustieteellisessä Seurassa kuitenkin syytä muistaa eräitä hänen toimenpiteitään erityisesti tutkimustyön hyväksi. Hän oli vuosina $1948-52$ silloisen maatalouden koetoiminnan keskusvaliokunnan puheenjohtajana. Hän näki nopeasti tutkimustoiminnan puutteet ja sen välttämättömät tarpeet. Tuo aika oli tutkimustoiminnalle sangen vaikeata, koska varoja tarvittiin ennen kaikkea jälleenrakentamiseen. Näinä vuosina koetoiminnan piirissä tapahtui erityisesti Perä-pohjolan ja Karjalan koeasemien kunnostamista. Tutkimusvälineistöäkin koetettiin hankkia ja tiedoitustoimintaa kehitettiin. Hänen puheenjohtajakaudellaan saatiin hallantutkimus käyntiin ja vähäisestä alusta on sittemmin syntynyt varsinainen hallakoeasema. Samoin laiduntutkimusta tehostettiin ja yhteistoiminnassa yliopiston kanssa perustettiin laidunkoekenttiä Viikin ja Malminkartanon koetiloille. Ensiksi mainitulla tilalla ovat nämä kokeet edelleen käynnissä. Ne ovat antaneet vuosien kuluessa erinomaisen runsaasti tuloksia. Ensi vuonna täällä pidettävässä kansainvälisessä laidunkongressissa niitä ja niiden tuloksia voidaan esitellä tavallista laajemmalle vierailijajoukolle.

Tässä yhteydessä ei ole unohdettava sitä, että Viding oli v. 1947 sen komitean puheenjohtaja, joka suunnitteli korkeimman maatalousopetuksen sijoituspaikaksi Viikin koetilan. Hänen oli erinomaisen helppo ymmärtää, että tehokasta maatalousopetusta ja siihen liittyvää tutkimustoimintaa voidaan harjoittaa vain ajanmukaisissa laitoksissa ja ympäristössä, jossa on jatkuvasti välitöntä kosketusta käytännön maatalouteen. Nyt kun osa tehdyistä suunnitelmista on voitu toteuttaa, on syytä korostaa hänen osuuttaan tämän kaukonäköiseen ratkaisun auttamiseksi.

Tutkimustyöstä puheenollen on muistettava, että Vidingillä oli keskeinen merkitys osuustoimintainstituutin aikaansaamisessa Helsingin yliopistoon v. 1957. Tämä suoraan konsistorin alainen laitos on syntynyt osuustoimintaliikkeiden muodostaman säätiön lahjoituksien turvin. Sen piirissä suoritetaan osuustoimintaa koskevaa objektiivista tutkimustyötä. Tuloksista voidaan mainita, että pisimmälle päässyt tutkija on nyt jo saavuttanut dosentin pätevyyden. Vain muutama päivä sitten instituutin toimesta järjestettiin kansainvälinen symposium, jossa osanottajia oli Intiasta, Yhdysvalloista, Neuvostoliitosta ja Saksasta.

Vuorineuvos Viding - hän oli saanut tämän arvon v. 1954 - tunsi aina suurta mielenkiintoa ja sympatiaa opiskelevaa nuorisoa kohtaan. Hän oli aktiivisesti mukana Latokartanon ylioppilaskylän rakentamisessa. Hänen puoleensa ovat ylioppilasjärjestöt kääntyneet usein apua tarvitessaan. On luonnollista, että karjalaiset ylioppilaat ovat olleet lähinnä hänen sydäntään, mutta yhtä hyvin kaikki muutkin ylioppilaspiirit ovat aina saaneet lämpimän vastaanoton hänen luonaan. Ylioppilaiden toimintaa hän seurasi jatkuvasti suurella mielenkiinnolla. Puheissaan ja keskusteluissa hän aina korosti isänmaallisen hengen tärkeyttä nimenomaan juuri ylioppilaspiireissä.

Paavo Viding oli luonteeltaan valoisa ja elämänmyönteinen. Hän oli aina valmis pohtimaan ammattikysymyksiä ja tekemään suunnitelmia olevien olojen parantamiseksi ja kohentamiseksi. Suunnitelmissaan hän pysyi vakavalla pohjalla. Niihin liittyi jokseenkin säännöllisesti yhteiseen hyvään viittaavia piirteitä. Koti- 
seutu ja Karjala olivat hänelle läheisiä ja Karjalan hyväksi hän oli aina valmis työskentelemään niin hyvin sodan aikana kuin rauhan vallitessa. Isänmaanvapaus ja itsenäisyys sekä niihin kiinteästi liittyvä maanpuolustus olivat hänelle hyvin läheisiä ja kuten jo edellä viittasin, hän kiinnitti erityistä huomiota nuorison kasvattamiseen isänmaallisessa hengessä. Hänen työnsä koko valtakunnan aineellisen kehityksen hyväksi oli erittäin monipuolista ja tuloksellista ja sitä kannusti lämmin isänmaan rakkaus. 